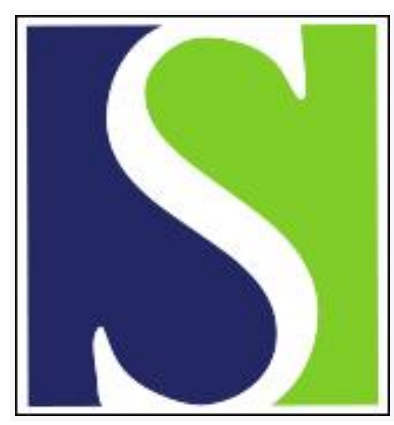

Scand J Work Environ Health 1977;3(3):135-143

https://doi.org/10.5271/sjweh.2780

Issue date: Sep 1977

\title{
Exposure of animals and man to toluene.
}

by Carlsson A, Lindqvist $T$

The following articles refer to this text: 1979;5(3):232-248;

1979;5(3):286-289

Key terms: adipose tissue; alveolar air; animal; exposure; man; organ concentration; rat; toluene; uptake

This article in PubMed: www.ncbi.nlm.nih.gov/pubmed/910123

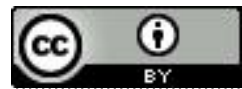




\title{
Exposure of animals and man to toluene
}

\author{
by ANDERS CARLSSON, M.D., and THOMAS LINDQVIST ${ }^{1}$
}

\begin{abstract}
CARLSSON, A. and LINDQVIST, T. Exposure of animals and man to toluene. Scand. j. work environ. \& health 3 (1977) 135-143. Twenty rats were exposed for 60 min to ${ }_{14} \mathrm{C}$-labeled toluene $\left(1,950 \mathrm{mg} / \mathrm{m}^{3}\right)$ in the inspired air. The largest amounts of toluene and its metabolites were found in the white adipose tissue. In a second series of experiments seven healthy male subjects were exposed to $375 \mathrm{mg} / \mathrm{m}^{3}$ of toluene in the air at rest and during light, moderate and heavy physical exercise on a bicycle ergometer. The duration of each exposure period was $30 \mathrm{~min}$. Of the seven male subjects three were thin, one was slightly overweight, and three were excessively overweight. The concentration of toluene in the alveolar air and the total uptake of toluene were determined during exposure. The thin subjects had a higher concentration of toluene in alveolar air than the other subjects both at rest and during exercise. The total uptake of toluene in the body during exposure showed that the subjects with the least amount of adipose tissue had the smallest uptake and the subjects with the largest amount of adipose tissue had the largest uptake.
\end{abstract}

Key words: adipose tissue, alveolar air, exposure, man, organ concentrations, rat, toluene, uptake.

People and animals exposed to an organic solvent in inspiratory air take up the solvent into the body via the pulmonary alveoli. From there the solvent is transported with the blood to various organs and tissues. The degree of affinity varies considerably for different tissues. However, adipose tissue always displays the greatest affinity (9).

Since the amount of adipose tissue differs between individuals, the total uptake of a solvent should be less in thin than in fat people under identical exposure conditions. Moreover, adipose tissue should become saturated more rapidly in a thin person than in a fat one when all other pertinent conditions are the same. Thus other organs should be exposed to higher

1 Work Physiology Unit, Department of Occupational Health, National Board of Occupational Safety and Health, Stockholm, Sweden.

Reprint requests to: Dr. Anders Carlsson, National Board of Occupational Safety and Health, S-100 26 Stockholm, Sweden. concentrations at an earlier stage in thin people than in fat ones. These circumstances should all influence the effect of solvents on man.

In order to test this hypothesis, we measured the organ concentrations attained after acute exposure to toluene in animals. Moreover, the total uptake in human subjects with varying degrees of adipose tissue was studied. We selected the solvent toluene for the study because of its widespread use in industry.

\section{DISTRIBUTION OF C-14 LABELED TOLUENE IN RAT}

\section{Experimental design}

Twenty male rats (Sprague-Dawley), each weighing about $200 \mathrm{~g}$, were used for the experiments (Anticimex, Sollentuna, Sweden).

The air mixture used in the exposure was prepared by the injection of a given 
quantity of radioactive toluene into a bag containing about $100 \mathrm{l}$ of air. A microliter syringe was used to make injections into the bag, which was specially made of polyester-laminated aluminium foil. The radioactive toluene, labeled in the methyl group, was obtained from Kebo-Grave, Stockholm, Sweden. The specific activity of the radioactive toluene varied from 8.22 to $12.65 \mu \mathrm{Ci} / \mathrm{mmol}$. The experimental animal was placed in a tight metabolism cage (150 mm inner diameter, Kebo-Grave, Sweden). The air mixture from the aforementioned bag flowed into the cage via a rotameter (model $1350 \mathrm{~V}, \mathrm{AB}$ Max Sievert, Vällingby, Sweden). Any surplus of the mixture was evacuated through a tube connected to a water suction unit. The entire device was placed in a fume cupboard. The flow rate, which was regulated with a tube clip, was set at $20 \mathrm{l} / \mathrm{h}$.

After $1 \mathrm{~h}$ of exposure to a toluene concentration of about $1,950 \mathrm{mg} / \mathrm{m}^{3}(550 \mathrm{ppm})$ in the inspiratory air the rats were killed by means of luxation of the cervical spine at the following times: either immediately after exposure (10 animals), $1 \mathrm{~h}$ after con- cluded exposure (5 animals) or $6 \mathrm{~h}$ after concluded exposure (5 animals). Specimens were taken from the liver, kidney, adrenal tissue, white adipose tissue, cerebrum and cerebellum. The specimens were then assayed for their content of radioactive toluene and its metabolites.

\section{Analytical methods}

The organ and tissue specimens were isolated, placed in glass scintillation vials (Packard Instrument $\mathrm{AB}$, Bandhagen, Sweden) and weighed. They were then digested in $1 \mathrm{ml}$ of Soluene-350 (Packard Instrument $\mathrm{AB}$ ) for $2-4 \mathrm{~h}$ at $+50^{\circ} \mathrm{C}$. Nine milliliters of a scintillation liquid consisting of Permablend III (Packard Instrument $A B$ ) dissolved in toluene was then added. The assays were performed with a liquid scintillation counter (model 2425 Tri Carb, Packard Instrument Co. Inc., Downers Grove, Ill., U.S.A.). Two samples were taken from each organ and tissue. Each specimen was measured in two cycles lasting $20 \mathrm{~min}$ or up to a maximum of

Table 1. Organ and tissue concentrations of toluene in rats exposed to a toluene concentration of $1,950 \mathrm{mg} / \mathrm{m}^{3}(550 \mathrm{ppm})$ for $1 \mathrm{~h}$. The mean value \pm the standard error of the mean (SE) and the standard deviation (SD) is stated. The method error, calculated as the mean difference between 20 double determinations, is given, as well as the partition coefficient for the different tissues according to Sato et al. (9).

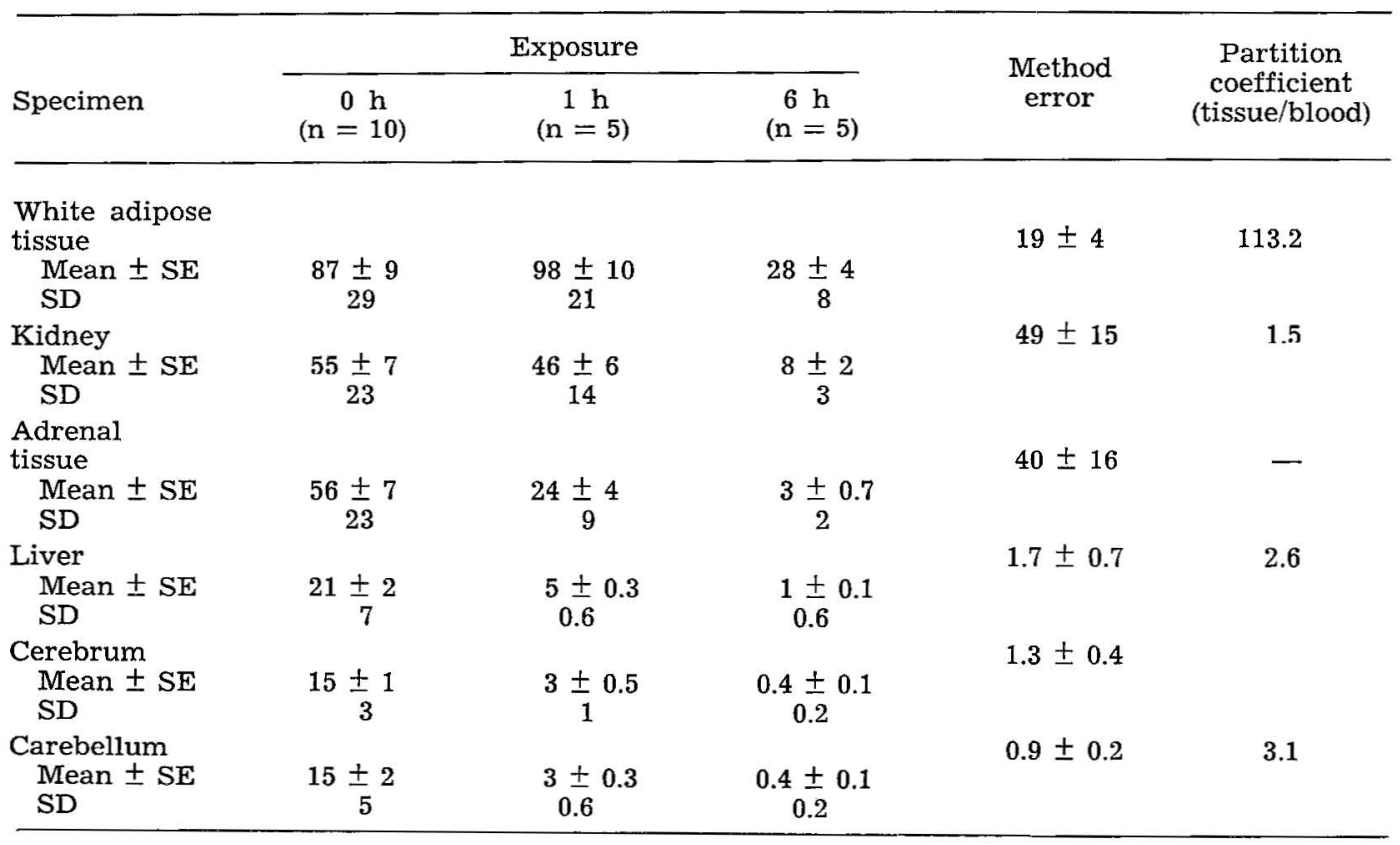




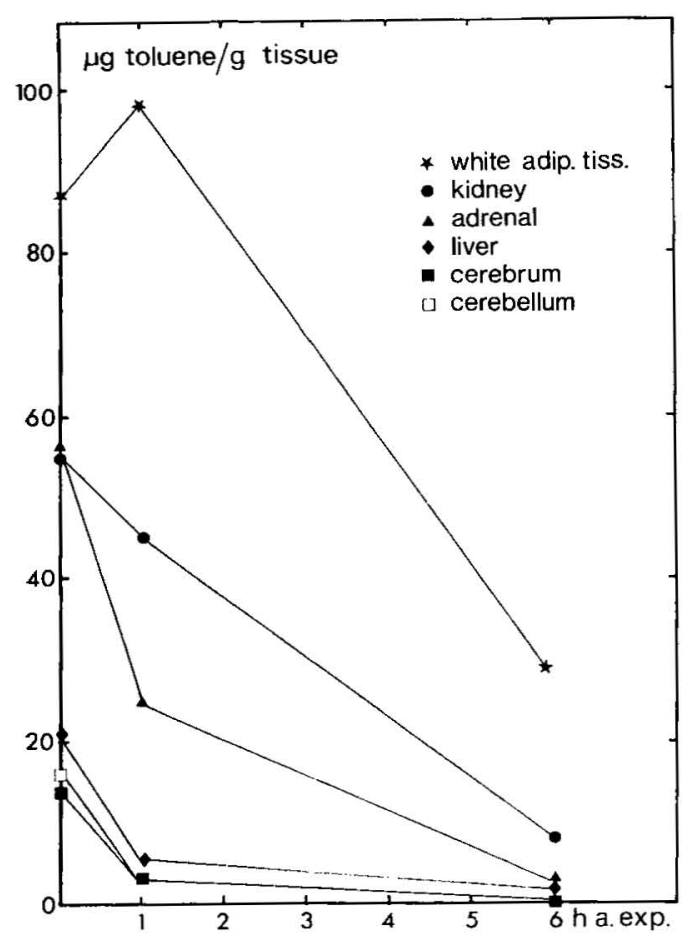

Fig. 1. The concentration of toluene and its metabolites in different organs and tissues of rat as a function of the time elapsed after concluded exposure. The animals were exposed to a toluene concentration of $1,950 \mathrm{mg} / \mathrm{m}^{3}$ (550 $\mathrm{ppm})$ for $1 \mathrm{~h}$.

20,000 impulses. The activity value for each specimen was calculated as the mean value of these two determinations. The mean value of the two specimens was stated. The error of the method for the equipment amounted to $\pm 0.7 \%$ at 20,000 impulses. The error of the method for a single determination for each organ or tissue is stated in table 1.

\section{Results}

The results of the measurements of the accumulation of radioactive toluene and its metabolites are shown in fig. 1 and table 1. As can be seen, the concentration was always the greatest in the white adipose tissue, followed consecutively by the concentrations in the kidney, adrenal tissue, liver, cerebrum, and cerebellum. Immediately after the conclusion of exposure, the concentration was about six times higher in white adipose tissue than in the cerebrum and cerebellum. One hour after concluded exposure the concentration remained unchanged in white adipose tissue but had dropped sharply in the liver, cerebrum, and cerebellum. Six hours after concluded exposure the concentration in white adipose tissue was about onethird of the initial value, whereas the concentration in the cerebrum and cerebellum had dropped to about one-thirtieth of the initial value.

\section{UPTAKE IN MAN DURING REST AND EXERCISE}

\section{Subjects}

Seven men from 23 to 29 years of age, three of whom were thin (subjects 1 to 3 ), one slightly overweight (subject 4) and three excessively overweight (subjects 5 to 7 ), served as the subjects. The amount of body fat was estimated by hydrostatic weighing according to von Döbeln (6). The subjects were given a clinical examination, and functional studies were made of their respiratory and circulatory organs during rest and exercise. The same method was used for the medical examination as in previous studies of solvents $(2,3$, 4,5 ). All the subjects were healthy at the time of the examination, and none of them had ever been afflicted with any disease that would have had an adverse effect on respiratory and circulatory organs. The hemoglobin concentration, the hematocrit level, and the sedimentation rate were within normal limits for all subjects. No subject had any albumin, blood or reducing substances in his urine. The results of spirometric examinations were normal (table 2). Two of the subjects were smokers. All values from both the submaximal and maximal exercise were normal. There were no significant differences between the mean values for the subjects in this study and the corresponding mean values for subjects in studies previously performed $(2,3,4,5)$ for heart rate, oxygen uptake, pulmonary ventilation, and blood lactate concentration at different exercise intensities. [For a detailed description of the methods used the reader should consult Asstrand and Övrum (5)]. 
Table 2. Body height, body weight, total amount of adipose tissue, and respiratory data taken at rest from seven male subjects 23 to 29 years of age. The means and ranges are stated. (FEV $\%=$ forced expiratory volume for $1 \mathrm{~s}$ as the percentage of vital capacity; $\mathrm{MVV}_{\mathrm{f}}=\mathrm{maximal}$ voluntary ventilation at free rate).

\begin{tabular}{|c|c|c|c|c|c|c|c|}
\hline Subject & $\begin{array}{l}\text { Body } \\
\text { height } \\
\text { (cm) }\end{array}$ & $\begin{array}{c}\text { Body } \\
\text { weight } \\
\text { (kg) }\end{array}$ & $\begin{array}{c}\text { Adipose } \\
\text { tissue } \\
\text { (kg) }\end{array}$ & $\begin{array}{l}\text { Vital } \\
\text { capacity, } \\
\text { BTPS } \\
\text { (1) }\end{array}$ & $\begin{array}{l}\text { Residual } \\
\text { volume, } \\
\text { BTPS } \\
\text { (I) }\end{array}$ & $\mathrm{FEV} \%$ & $\begin{array}{l}\mathrm{MVV}_{\mathrm{f}} \\
(\mathrm{l} / \mathrm{min})\end{array}$ \\
\hline \multicolumn{8}{|l|}{$1-3$} \\
\hline Mean & 184 & 73.3 & 6.0 & 6.0 & 2.0 & 83.1 & 225.5 \\
\hline Range & $174-196$ & $58.3-94.7$ & $1.4-10.7$ & $5.5-7.0$ & $1.6-2.8$ & $78.0-88.0$ & $179.6-251.0$ \\
\hline 4 & 181 & 97.1 & 22.8 & 4.8 & 2.0 & 71.9 & 164.2 \\
\hline \multicolumn{8}{|l|}{$5-7$} \\
\hline Mean & 192 & 125.1 & 44.0 & 6.8 & 1.8 & 80.0 & 191.6 \\
\hline Range & $188-195$ & $119.8-133.9$ & $35.1-49.0$ & $6.6-7.0$ & $1.7-2.0$ & $75.6-86.8$ & $181.3-208.0$ \\
\hline
\end{tabular}

\section{Experimental design}

The subjects were exposed at rest and during exercise on a bicycle ergometer through a valve to a concentration of toluene in inspiratory air close to the Swedish threshold limit value, i.e., 100 $\mathrm{ppm}$ (corresponding to $375 \mathrm{mg} / \mathrm{m}^{3}$ at $25^{\circ} \mathrm{C}$ and at a barometric pressure of $760 \mathrm{~mm}$ $\mathrm{Hg}$ ). The air mixture was prepared in the same manner as in previous studies $(2,3,4,5)$. The concentration of toluene in inspiratory air was continuously monitored with a gas indicator (Hydrocarbon analyzer, model 116, Scott Research Lab. Inc., Plumsteadville, Pa., U.S.A.). The actual levels varied from 370 to $391 \mathrm{mg} / \mathrm{m}^{3}$ at an intended concentration of $375 \mathrm{mg} / \mathrm{m}^{3}$.

The exposure periods lasted for $30 \mathrm{~min}$, and each subject was exposed during four consecutive periods at each session, i.e., for a total of $2 \mathrm{~h}$. The session was comprised of one period of rest and three of exercise at the intensities of about $50 \mathrm{~W}$ $(300 \mathrm{kpm} / \mathrm{min}), 100 \mathrm{~W}(600 \mathrm{kpm} / \mathrm{min})$, and

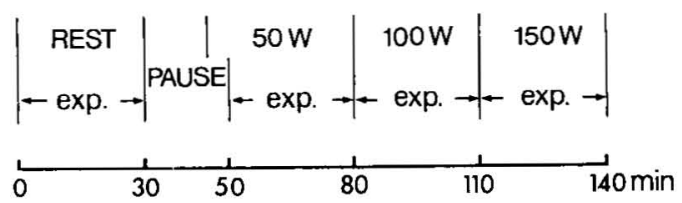

Fig. 2. Seven subjects were exposed during one 30-min period of rest and three of exercise consecutively. A 20 -min pause without exposure was inserted in the transition between rest and exercise. Exposure concentration: 375 $\mathrm{mg} / \mathrm{m}^{3}$ of toluene in inspiratory air.
$150 \mathrm{~W}(900 \mathrm{kpm} / \mathrm{min})$, respectively (fig. 2). At a work intensity of $50 \mathrm{~W}$ the subjects utilized an average of $29 \%$ of their maximal aerobic work power. At 100 and $150 \mathrm{~W}$ they utilized about 45 and $63 \%$, respectively. These percentage figures, together with the measurements made during exposure, suggest that $50 \mathrm{~W}$ can be regarded as relatively light work for these subjects, $100 \mathrm{~W}$ as moderately heavy work, and $150 \mathrm{~W}$ as heavy work. The subjects completed the different exposure periods without any unpleasant effects. No significant ECG changes were recorded at rest or during exercise. The time for measurements and sampling in relation to each exposure period is shown in fig. 3 .

Alveolar air samples for the toluene assays were extracted with a glass syringe from the expiratory valve during exposure. Throughout the entire exposure, i.e., for $2 \mathrm{~h}$, the expiratory air was collected continuously in bags, and the volume was measured in a balanced spirometer. The bags were specially made of polyester-laminated aluminium foil. The toluene content in each bag was analyzed. The volume of inspiratory air was estimated as being the same as the volume of expiratory air, and the uptake of toluene in the organism was calculated as the difference between the total amount in inspiratory and expiratory air.

\section{Methods of analysis}

The toluene concentration in alveolar air was determined with a gas chromatograph 


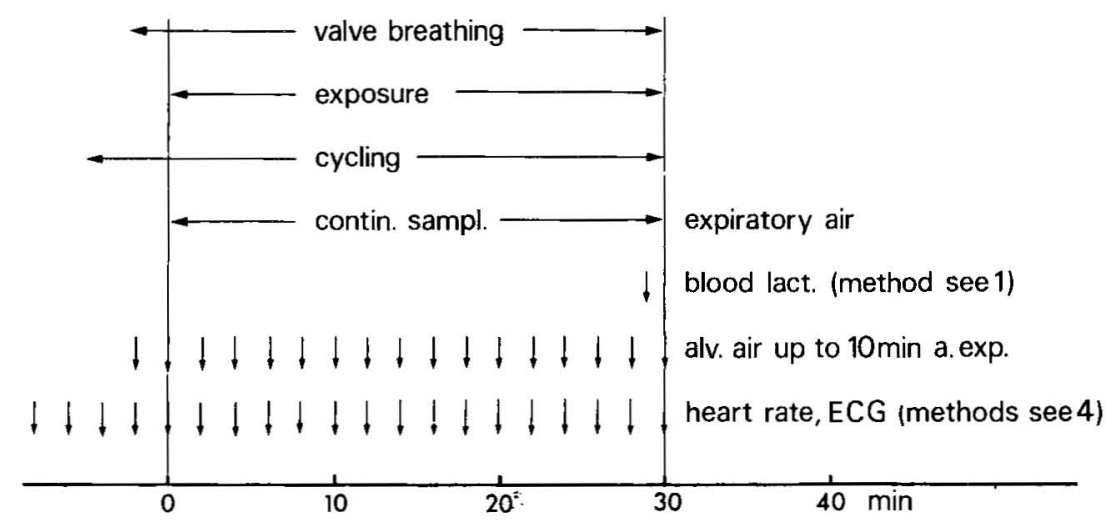

Fig. 3. Times for the different measurements and samplings during and, where applicable, before and after an exposure period lasting $30 \mathrm{~min}$.

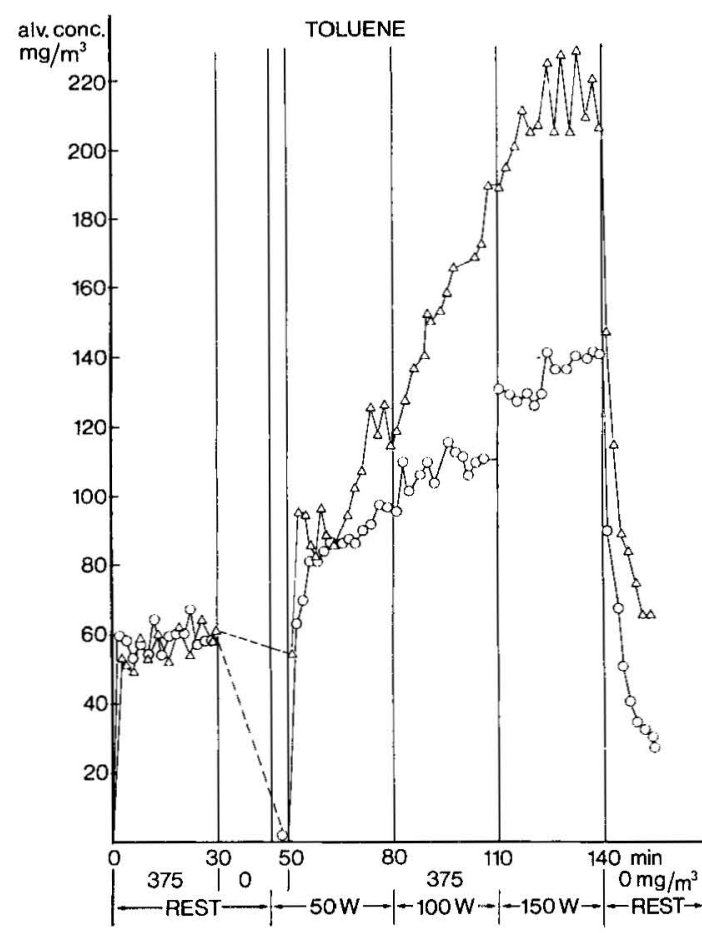

Fig. 4. Concentration of toluene in the alveolar air of one of the thin $(\triangle)$ and one of the overweight (o) subjects during and after exposure to about $375 \mathrm{mg} / \mathrm{m}^{3}$ of toluene in inspiratory air. Exposure was applied at rest and during exercise at intensities of 50,100 and $150 \mathrm{~W}$.

(model F 11, FID, Perkin-Elmer Ltd., Beaconsfield, Buckinghamshire, England) fitted with a stainless steel column (inner diameter $2.2 \mathrm{~mm}$, length $2 \mathrm{~m}$ ) and packed with $8 \%$ Carbowax on Chromosorb W,
$80-100$ mesh. The flow rate of the carrier gas (nitrogen) was $30 \mathrm{ml} / \mathrm{min}$, and the column temperature was $60^{\circ} \mathrm{C}$. Samples of $0.5 \mathrm{ml}$ were injected.

The concentration of toluene in inspiratory and expiratory air was determined with a gas chromatograph (model F 30, FID, Perkin-Elmer Ltd., Beaconsfield, Buckinghamshire, England) fitted with a stainless steel column (inner diameter 2.2 $\mathrm{mm}$, length $2 \mathrm{~m}$ ) and packed with $1 \%$ Fractonitril II on Chromosorb G, 80-100 mesh. The carrier gas flow rate was 30 $\mathrm{ml} / \mathrm{min}$, and the column temperature was $70^{\circ} \mathrm{C}$. Samples of $0.5 \mathrm{ml}$ were injected. The toluene concentration was determined from the chromatogram with the aid of standard air samples with known toluene concentrations.

\section{Results}

Alveolar air concentration during exposure. A definite interindividual difference was found in alveolar concentration during exposure. Subjects $1-3$ (thin) had a higher alveolar concentration than the others during rest and at all work loads (fig. 4). In all exposure periods, subject 4 displayed an alveolar air concentration that was higher than the mean value for subjects 5-7 (table 3).

Uptake in the organism. Quite logically, the uptake of toluene correlated with the alveolar air concentration (fig. 5). The higher the uptake, the lower the alveolar 
Table 3. The alveolar concentration at rest and during exercise at 50,100 and $150 \mathrm{~W}$ for the thin subjects $(1-3)$, for subject 4 , and for the overweight subjects (5-7). The means and ranges are given in milligrams per cubic meter. The means and ranges are stated. The mean values are also given as the percentage of the mean for subjects $5-7$.

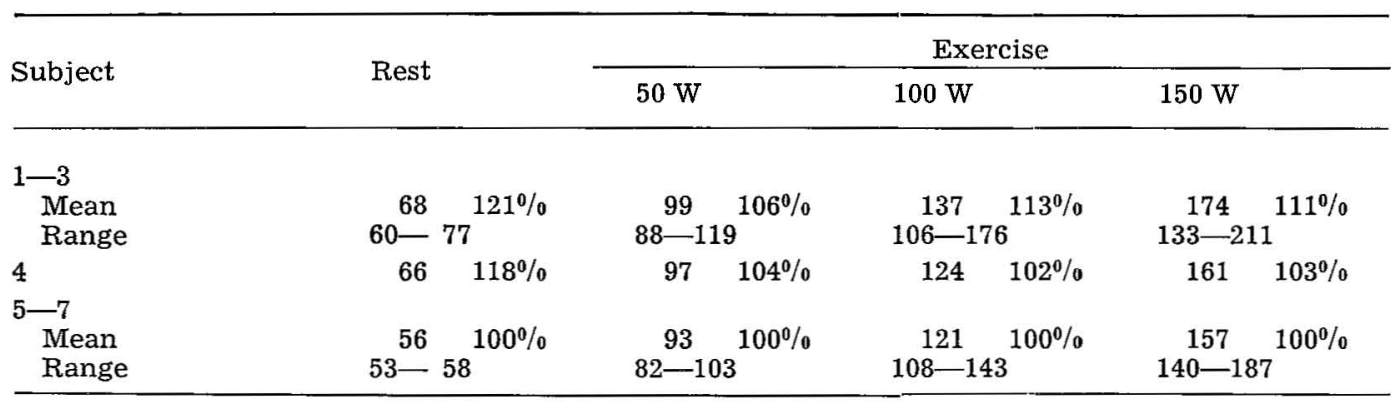

Table 4. Uptake of toluene in milligrams in three thin (subjects 1-3), one slightly overweight (subject 4) and three definitely overweight (subjects 5-7) subjects during exposure to a toluene concentration of $375 \mathrm{mg} / \mathrm{m}^{3}$ in the inspiratory air. The subjects were exposed during one 30min period of rest and three of exercise (intensities 50,100 and $150 \mathrm{~W}$ ) consecutively. The means are also given as the percentage of the mean for subjects $5-7$.

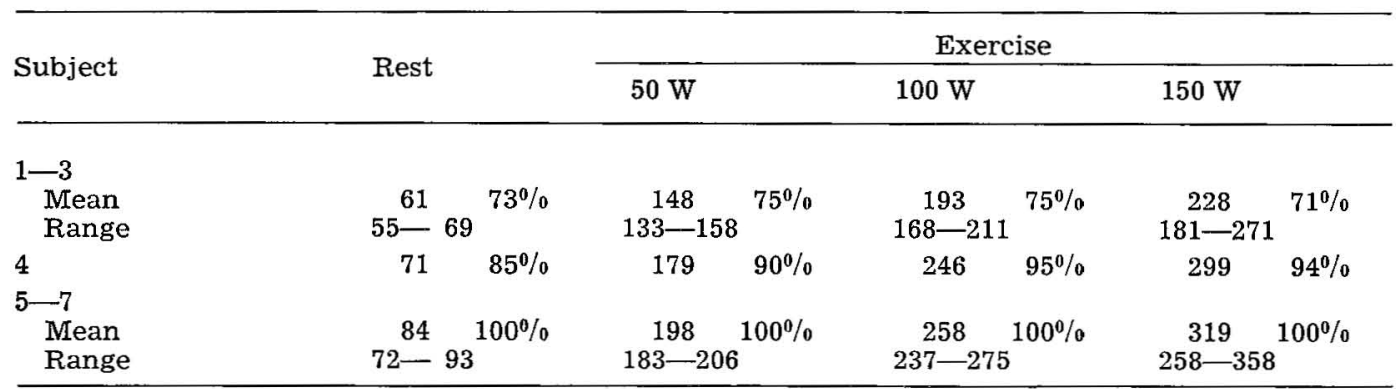

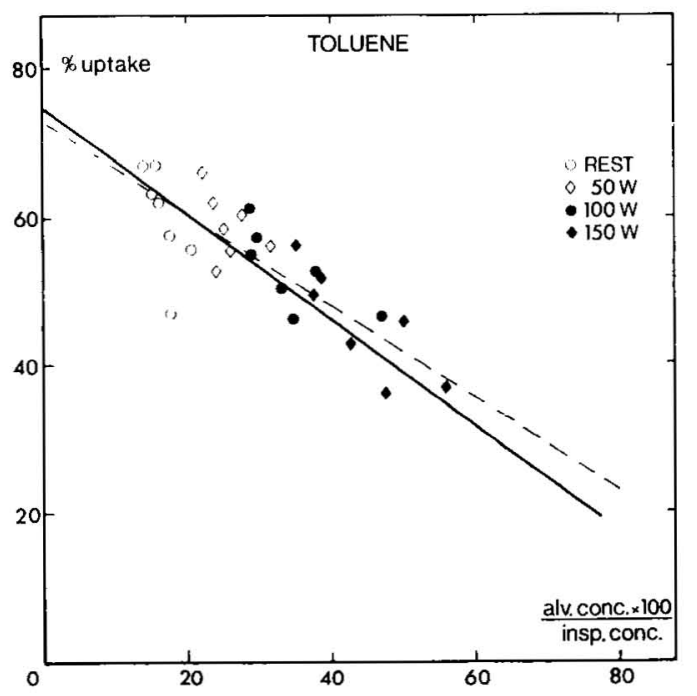

air concentration. From table 4 it is clear that the thin subjects (subjects 1-3) had the smallest uptake and the overweight subjects (subjects $5-7$ ) the highest. In other words, the subjects with the smallest amount of body fat had the smallest uptake and the subjects with the largest amount of body fat had the highest up-

Fig. 5. Uptake of toluene as the percentage of the amount supplied in relation to the alveolar concentration as the percentage of the concentration in inspiratory air after $30 \mathrm{~min}$ of exposure during rest and exercise. The straight line was taken from Astrand (1). The equation for the broken line is $y=-0.63 x+72.9$; $\mathrm{r}=0.85 ; \mathrm{SD}= \pm 4.9$. The two lines are almost identical. 

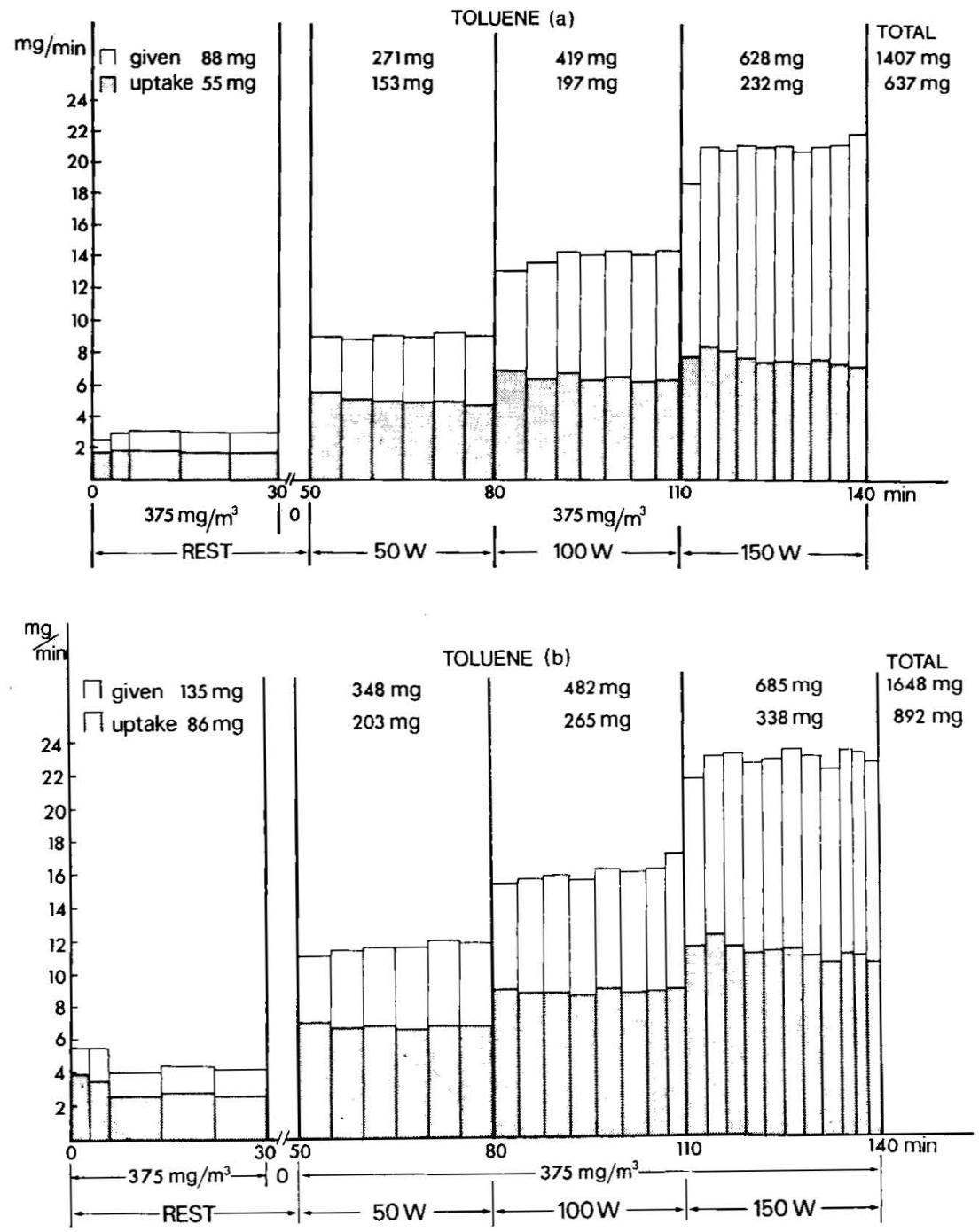

Fig. 6. The amount of toluene supplied and taken up in one thin (a) and in one overweight subject (b) during rest and during exercise at 50,100 and $150 \mathrm{~W}$. Toluene exposure of $375 \mathrm{mg} / \mathrm{m}^{3}$ was provided for $2 \mathrm{~h}$. ( $\mathrm{a}=$ same experiment and subject as $\triangle$ and $\mathrm{b}=$ same experiment and subject as 0 in fig. 4)

take (fig. 6). There was a statistically significant correlation between the total toluene uptake and the amount of body fat (fig. 7).

\section{DISCUSSION}

In the organism, toluene is biotransformed according to the following pattern: toluene $\longrightarrow$ benzyl alcohol $\longrightarrow$ benzaldehyde $\longrightarrow$ benzoic acid $\longrightarrow$ hippuric acid.
The hippuric acid is excreted in the urine. According to Williams (10) and Pagnotto and Liebermann (8) about three-fourths of the toluene taken up is biotransformed in this manner; the remainder is eliminated unchanged through the lungs.

The large variation in the radioactivity found in the rat kidneys in our experiments is probably ascribable to the accumulation of urine metabolites of toluene in the kidneys. The amount of urine in the samples varied to a great extent. The 


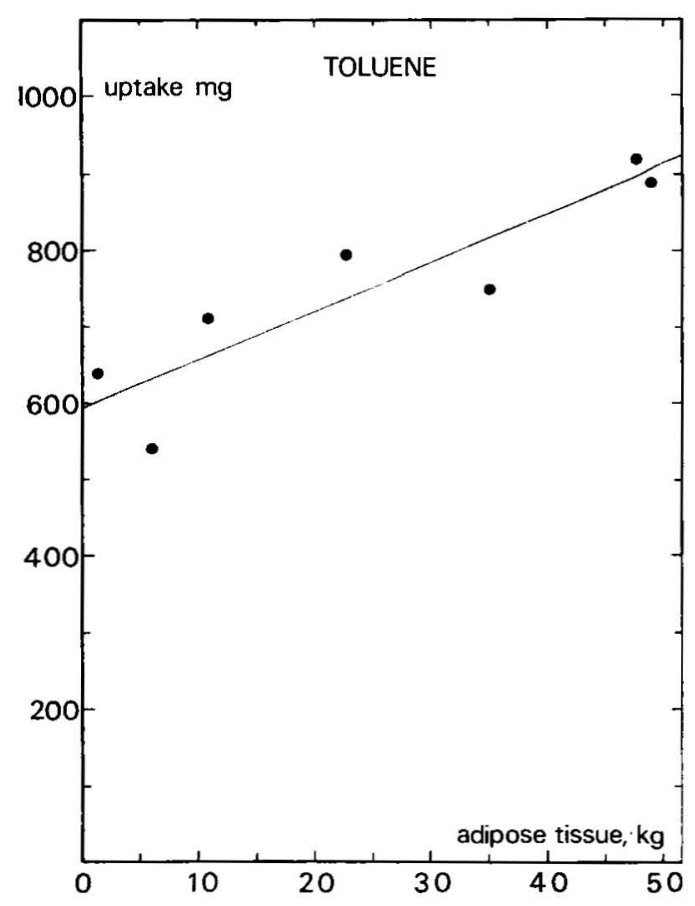

Fig. 7. Total uptake of toluene in milligrams during $2 \mathrm{~h}$ of exposure in relation to adipose tissue in kilograms. The exposure was applied at rest and during exercise at intensities of 50, 100 and $150 \mathrm{~W}$. Each dot represents one subject. The equation of the line is: $y=6.3 \mathrm{x}$ $+595 ; \mathrm{r}=0.91 ; \mathrm{SD}= \pm 67$

high radioactivity of the liver at the end of exposure was probably also due to the biotransformation of toluene. Toluene is converted into hippuric acid in the liver.

The very high radioactivity in white adipose tissue was due to the fact that toluene has a higher affinity for fat than for other tissues. Toluene has a high partition coefficient for fat/blood in relation to the coefficient for other tissues/ blood. The partition coefficient for tissue /blood for any specific substance is the ratio between the concentrations of the substance in tissue and blood at a given temperature and in equilibrium. The coefficient is usually determined at $37^{\circ} \mathrm{C}$. In the present study the pattern found for the distribution of toluene in the different tissues closely agreed - except in the kidney - with the partition coefficients given in table 1 . The fact that the concentrations were not proportional to the partition coefficients was probably because equilibrium was never attained in our experiments. Another factor of significance in this context, i.e., in addition to metabolism and partition coefficients, is the flow of blood to different tissues and organs. A different rate of blood flow may be the reason that our results did not agree with those reported by Fabre et al. (7).

Thus the present results can be explained by the biotransformation of toluene and by the affinity of toluene for different tissues. The rat experiments showed that adipose tissue is very important to the uptake of toluene. We performed the studies with human subjects in order to shed further light on the role of adipose tissue.

In previous toluene exposures of 10 subjects with an average amount of body fat of $5.7 \mathrm{~kg}$, the alveolar air concentration in exposure to $100 \mathrm{ppm}\left(375 \mathrm{mg} / \mathrm{m}^{3}\right)$ at rest amounted to a mean level of $68 \mathrm{mg} /$ $\mathrm{m}^{3}(2)$. This value should be compared to the mean value of $68 \mathrm{mg} / \mathrm{m}^{3}$ for subjects $1-3$ and to $66 \mathrm{mg} / \mathrm{m}^{3}$ for subject 4 in the present study. The comparison indicates a close agreement between the values. The mean level for the overweight subjects (subjects 5-7) amounted to $56 \mathrm{mg} / \mathrm{m}^{3}$.

The alveolar concentrations in subjects with a small amount of adipose tissue were higher than in subjects with a large amount of adipose tissue. This finding suggests that the greater uptake via the alveolar membranes in subjects with a large amount of body fat might have been due to the fact that their fat stores failed to attain the same concentration as in subjects with a small amount of body fat.

The greater part of the total uptake was probably supplied to the inner organs (cf. the intercept for the line in fig. 7). From earlier experiments we know that the blood concentration is fairly low (1). Thus the consequence of brief exposure to toluene might be that both thin and fat people run about the same risk of acquiring a high concentration in their central nervous systems, probably because the blood supply to adipose tissue is poorer than to other tissues. The total uptake of toluene in adipose tissue would therefore be low during brief exposure, despite 
the great affinity of toluene for adipose tissue. On the other hand, during prolonged exposure to toluene, a person with a large amount of body fat is probably exposed to a more prolonged effect on his central nervous system than a thin person since the toluene disappears more slowly from his adipose tissue and blood. Thus it takes longer to detoxicate someone with a large amount of body fat than someone with a small amount.

\section{REFERENCES}

1. ÅTRAND, I. Uptake of solvents in blood and tissues of man: A review. Scand. $j$. work environ. \& health 1 (1975) 199-218.

2. ÅSTRAND, I., EHRNER-SAMUEL, H., KILBOM, $\AA$. and ÖVRUM, P. Toluene exposure: I. Concentration in alveolar air and blood at rest and during exercise. Work-environ.-health 9 (1972) 119-130.

3. ÅSTRAND, I., KILBOM, . A., . OVRUM, P., WAHLBERG, I. and VESTENBERG, $O$. Exposure to styrene: I. Concentration in alveolar air and blood at rest and during exercise and metabolism. Work-environ. health 11 (1974) 69-85.

4. ÅTRAND, I., KILBOM, A., WAHLBERG, I. and OVRUM, P. Methylchloroform exposure: I. Concentration in alveolar air and blood at rest and during exercise. Work-environ.-health 10 (1973) $69-81$.

5. ÅSTRAND, I. and ÖVRUM, P. Exposure to trichloroethylene: I. Uptake and distribution in man. Scand. j. work environ. \& health 4 (1976) 199-211.

6. DÖBELN, W. VON. Anthropometric determination of fat-free body weight. Acta med. scand. 165 (1959) 37-40.

7. FABRE, R., TRUHAUT, R., BERNICHON, J. and LOISILLIER, F. Recherches toxicologiques sur les solvants de remplacement de benzène. Arch. mal. prof. med. trav. secur. soc. 16 (1955) 197-215.

8. PAGNOTTO, L. and LIEBERMANN, L Urinary hippuric acid excretion as an index of toluene exposure. Am. ind. hyg. assoc. j. 28 (1967) 129-134.

9. SATO, A., NAKUJIMA, T., FUJIWARA, Y. and HIROSAWA, K. Pharmacokinetics of bensene and toluene. Int. arch. arbeitsmed. 33 (1974) 169-182.

10. WILLIAMS,.. R. T. Detoxication mechanisms. Chapman and Hall Ltd., London 1959, pp. $194-195$.

Received for publication: 1977-04-18 